\title{
Benthic decapod crustaceans associated with captures of Munida spp. (Decapoda: Anomura) in the Beagle Channel, Argentina*
}

\author{
PATRICIA PÉREZ-BARROS ${ }^{1,2}$, FEDERICO TAPELLA² $^{2}$ M. CAROLINA ROMERO ${ }^{2}$, \\ JAVIER A. CALCAGNO ${ }^{1}$ and GUSTAVO A. LOVRICH ${ }^{2}$ \\ ${ }^{1}$ Universidad de Buenos Aires, Facultad de Ciencias Exactas y Naturales, Depto. Ecología, Genética y Evolución - Lab. \\ 109, $4^{\circ}$ Piso, Pab. II, Ciudad Universitaria, C1428EHA Buenos Aires, Argentina. \\ ${ }^{2}$ Consejo Nacional de Investigaciones Científicas y Técnicas, Centro Austral de Investigaciones Científicas, CADIC - CC \\ 92, V9410BFD Ushuaia, Tierra del Fuego. Argentina. E-mail: lovrich@tierradelfuego.org.ar
}

\begin{abstract}
SUMMARY: Benthic decapod crustacean assemblages in the Beagle Channel are dominated by the galatheid crabs Munida subrugosa and Munida gregaria. This study deals with the bathymetric and spatial distribution, density and diversity of the assemblage of decapod species that co-occur with Munida spp. in the Beagle Channel. A total of 131 samples were obtained using an epibenthic trawl from February 1999 to December 2000. They were taken monthly from two depth strata separated by the $40 \mathrm{~m}$ isobath (range: 4-262 m), and from three different sites: Bahía Lapataia, Ushuaia and Punta Segunda. Sixteen of the 36 recorded species of decapod crustaceans from the Beagle Channel were caught. Munida subrugosa and M. gregaria contributed $94 \%$ to the total decapod material. Of the remaining 6\%, Austropandalus grayi (Caridea) was the most abundant species, constituting $43 \%$ of the non-galatheid decapod fraction. Some species, namely Pagurus comptus and Eurypodius spp., were characteristic of shallow waters $(<40 \mathrm{~m})$, while others like Campylonotus semistriatus occurred in deeper waters $(>40 \mathrm{~m})$. The average density and diversity of non-galatheid decapods varied with depth and location. Decapod diversity correlated positively with the density of algae and polychaete tubes. The influence of three-dimensional bottom structure on decapod diversity in the Beagle Channel is discussed.
\end{abstract}

Key words: decapod crustaceans, benthos, species composition, distribution, Magellan region.

RESUMEN: CRUSTÁCEOS DECÁPodos BENTÓNICOS ASOCIAdOS A LAS CAPTURAS DE MUNIDA SPP. (DeCAPODA: ANOMURA) EN el Canal Beagle, ArgentinA. - Los galateidos Munida subrugosa y M. gregaria dominan las capturas bentónicas en el Canal Beagle. En el presente trabajo se estudia la distribución batimétrica y espacial, la densidad y la diversidad del ensamble de crustáceos decápodos capturados junto con Munida spp. en el Canal Beagle. Entre febrero de 1999 y diciembre de 2000, se tomaron 131 muestras con una red epibentónica de arrastre en 2 estratos de profundidad separados por la isobata de 40 m (rango: 4-262 m), y en tres localidades: Bahía Lapataia, Ushuaia y Punta Segunda. Se registraron 16 de las 36 especies de decápodos citadas para el Canal Beagle. Munida subrugosa y M. gregaria constituyeron el $94 \%$ de los decápodos capturados. Del $6 \%$ restante, Austropandalus grayi (Caridea) fue la especie dominante y constituyó el $43 \%$. Se observó una distribución batimétrica diferencial, con especies características de aguas poco profundas $(<40 \mathrm{~m})$, como Pagurus comptus y Eurypodius spp., y otras de aguas profundas ( $>40 \mathrm{~m})$, como Campylonotus semistriatus. La densidad y diversidad de los decápodos no galateidos varió con la profundidad y la localidad. La diversidad correlacionó positivamente con la densidad de algas y tubos de poliquetos. Se discute la influencia de la estructura tridimensional del fondo sobre la diversidad de decápodos en el Canal Beagle.

Palabras clave: crustáceos decápodos, bentos, composición de especies, región de Magallanes.

*Received March 3, 2003. Accepted October 10, 2003. 


\section{INTRODUCTION}

The Beagle Channel is located in southernmost South America and constitutes a key environment for the study of interactions between the sub-Antarctic region and the Antarctic. From the Magellan region to Antarctica, there is a sharp decline in key benthic groups such as crustaceans (Crame, 1999). Benthic Anomura and Brachyura are practically absent from Antarctic waters, where caridean shrimps are dominant (Gorny, 1999). Decapods of the Antarctic continental shelves are currently known to extend their distribution range towards the southern tip of South America (Gorny, 1999).

The decapod fauna of the Magellan region is well known, especially from recent surveys carried out in the coastal sub-Antarctic environment around Tierra del Fuego (e.g. Arntz et al., 1999; Mutschke and Gorny, 1999; Retamal and Gorny, 2001). These studies were aimed at finding differences within the Magellan region, and among the diverse environments represented by the different channels and fjords. In this region, five species assemblages were identified, in which the specific composition is explained by water depth, the presence of soft sediment and the occurrence of biogenic debris (Gutt et al., 1999).

The brachyuran crab Peltarion spinosulum is one of the dominant species of decapods found in the Strait of Magellan and the channel system south of it, whereas Munida spp. is dominant south of the Beagle Channel (Arntz et al., 1999; Gutt et al., 1999). However, these studies excluded the sector of the Beagle Channel shared by Argentina and Chile, and most of the samples were taken at depths of $>30$ m (c.f. Arntz and Gorny, 1996). This sector of the Beagle Channel is shallower than its western part (Antezana, 1999a), and approximately 50\% of its area is $<50 \mathrm{~m}$ deep and greatly characterised by Macrocystis pyrifera kelp forests. Moreover, previous studies dealing with crustacean distribution in the Magellan region were only semi-quantitative (Arntz et al., 1999).

The anomurans $M$. subrugosa and $M$. gregaria are the dominant species in the Beagle Channel and its eastern entrance. In terms of biomass both species contribute $50 \%$ to the benthic community (Arntz et al., 1994) and in terms of numbers they represent $>90 \%$ of the decapod fauna (Arntz et al., 1999). In 1999 and 2000, in a sector of $45 \mathrm{~km}$ of the Beagle Channel, the biomass of $M$. subrugosa was of $2.7 \mathrm{t} \cdot \mathrm{km}^{-2}$ (Tapella, 2002).
In the present study we analyse the bathymetric and spatial distribution, density and diversity of the assemblage of decapod species that co-occur with Munida spp. in the Beagle Channel. Our aim is to complement the available information about the distribution of decapod species in a sector of the Beagle Channel not previously surveyed. We provide comparisons between 3 different locations within the Beagle Channel, each revealing different environmental characteristics.

\section{METHODS}

\section{Study site and sampling}

The study was carried out in the Beagle Channel (ca. $55^{\circ} \mathrm{S} 68^{\circ} \mathrm{W}$ ) between Bahía Lapataia and Punta Segunda (Fig. 1). In the Beagle Channel the surface water temperature averages $6.7^{\circ} \mathrm{C}$ over the year and ranges from $4.2-4.3^{\circ} \mathrm{C}$ in August to $8.9-9.8^{\circ} \mathrm{C}$ in January. Salinity ranges from 26.7 in NovemberDecember to 31.3 during July (Balestrini et al., 1998).

Sampling was performed on a monthly basis from February 1999 to December 2000, and was intended to capture Munida spp. (c.f. Tapella, 2002). A total of 131 samples were obtained with an epibenthic trawl of $1.7 \mathrm{~m}$ mouth width and a $10 \mathrm{~mm}$ mesh net. For each sampling period two samples, one at $<40 \mathrm{~m}$ and one at $>40 \mathrm{~m}$, were randomly obtained from each of the 3 sampling locations (Bahia Lapataia, Ushuaia and Punta Segunda). The $40 \mathrm{~m}$ isobath is known to be the lower bathymetric distribution of benthic macroalgae, as for e.g. the dominant Macrocystis pyrifera (Kühnemann, 1970). The 3 sampling locations were chosen according to the effect that their environmental characteristics could have on decapod distribution. "Bahía Lapataia" is a paleo-fjord, with a great inflow of fresh water run-off from the Río Roca and a limited water exchange with the rest of the Beagle Channel, and hence with estuarine characteristics. "Ushuaia" has shallow waters of ca. $30 \mathrm{~m}$ depth and islands surrounded by kelp forests of $M$. pyrifera, and "Punta Segunda" has a steep slope and strong water currents (Fig. 1).

Tows were carried out during daylight at a speed of $0.65-0.80 \mathrm{~m} \cdot \mathrm{s}^{-1}$ for $5-25$ minutes (mostly $5 \mathrm{~min}$ ). The range of fishing depths extended from 4 to 262 $\mathrm{m}$. The initial and final positions of each tow were recorded with a geostationary satellite positioning 

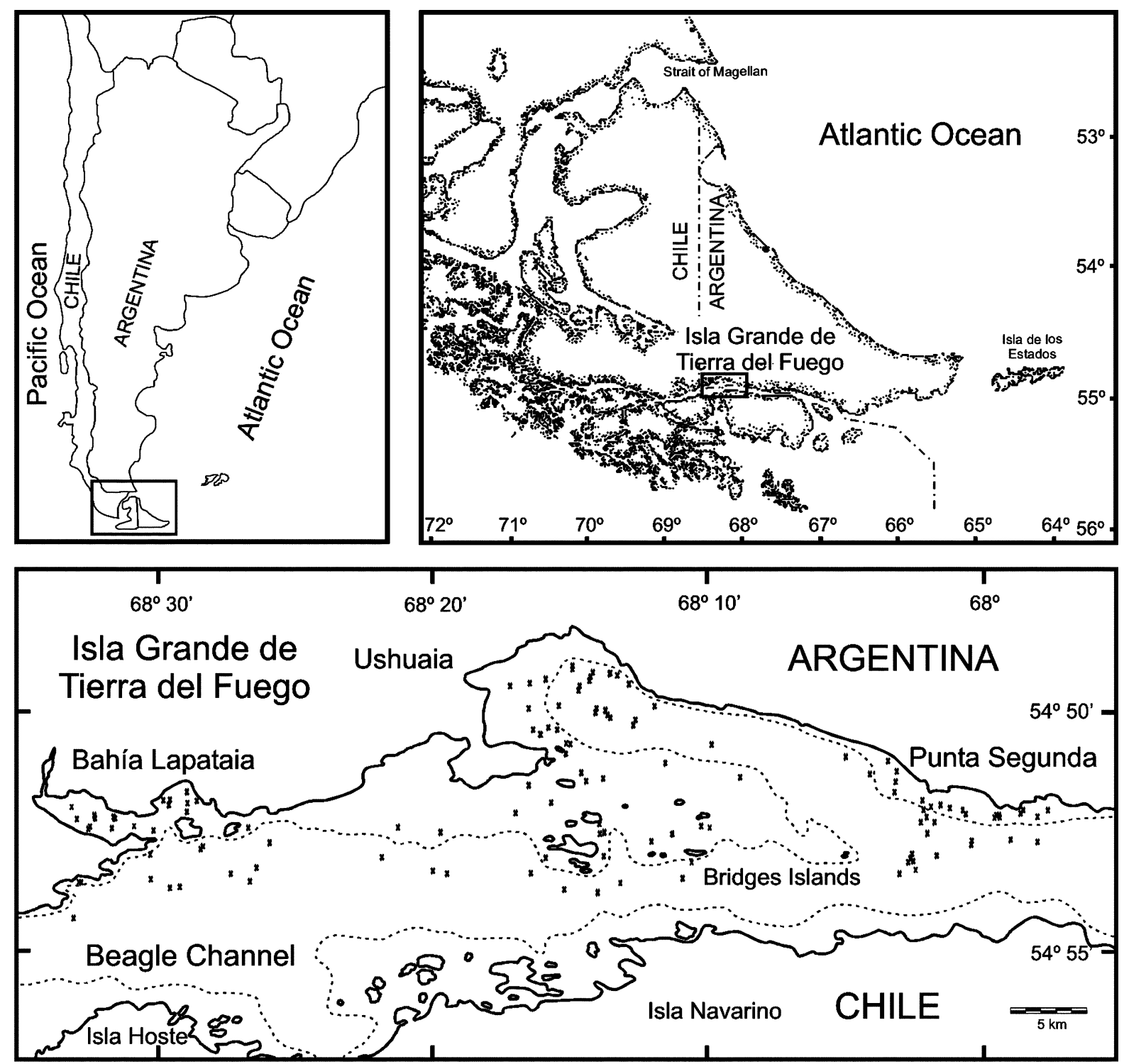

FIG. 1. - Study area in the Beagle Channel. Crosses indicate sampling stations. The $50 \mathrm{~m}$ isobath is indicated with the broken line.

system with a precision of $15 \mathrm{~m}$. The maximum depth of each tow was recorded with a portable echo-sounder. All samples were immediately fixed in $4 \%$ formalin in seawater.

In the laboratory, all decapods were determined to species level based on the available literature (Garth, 1957; Holthuis, 1952; Retamal, 1973; 1981; 2000; Torti and Boschi, 1973; Boschi et al., 1992) and enumerated. The two species of the genus Eurypodius reported for the Magellan region, E. latreillei and $E$. longirostris, can be identified on the basis of their rostrum length and shape (Retamal, 2000). However, the rostrum of most animals caught was damaged and their specific identity could not be determined. Therefore, both species are presented as Eurypodius spp.
Algae biomass, polychaete tubes, and fine litterfall of terrestrial origin (mostly leaves and twigs $<1$ $\mathrm{cm}$ diameter of the southern beech Nothofagus spp.) collected in each tow were blotted on absorbent paper and weighed with a balance of $0.01 \mathrm{~g}$ precision.

\section{Density of decapod crustaceans}

Decapod densities were calculated using the tow distance and the trawl width, and are presented as number of individuals per $10,000 \mathrm{~m}^{2}$. The tow distance over the bottom was estimated as the difference between boat positions at the beginning and at the end of each tow.

When data deviated significantly from a normal distribution (Kolmogorov-Smirnov test), the non- 
parametric Mann-Whitney rank sum test was used to compare species densities at both depth strata (Sokal and Rohlf, 1995). A two-way analysis of variance was used to evaluate the influence of depth and sampling location on non-galatheid decapod density. Density was transformed to $\log ($ density +1$)$ to comply with normality and homoscedasticity. These assumptions were tested with a Kolmogorov Smirnov and Bartlett test respectively (Sokal and Rohlf, 1995). Planned comparisons were used to test for differences between particular data sets.

The spatial analysis of each species density per tow was performed using Surfer Version 7.00 (Golden Software, Inc.) and a digitalised map. For this purpose, the map was modified and islands were not included in order to avoid confusions between density plots and islands. Decimal coordinates were used in these maps.

\section{Diversity of the decapod assemblages}

Richness ( $\mathrm{R}=\log _{2}$ of species number), diversity (H Shannon index in $\log _{2}$ ) and evenness $(E=H / R)$ were calculated for each tow (Magurran, 1988). A two-way ANOVA was used to analyse the influence of depth and location on diversity (Sokal and Rohlf, 1995). Planned contrasts were used to make specific comparisons. Samples in which non-galatheid decapods were absent were excluded from the analysis due to the impossibility of calculating $\mathrm{R}$ and $\mathrm{H}$.

Pearson's correlations were calculated to evaluate the relationship between diversity and several environmental variables. These included density of algae $\left(\mathrm{kg} \cdot 10,000 \mathrm{~m}^{-2}\right)$ and polychaete tubes $(\mathrm{kg} \cdot$ $10,000 \mathrm{~m}^{-2}$ ), which occurred in the same tows.

\section{RESULTS}

A total of 16 of the 36 known species of decapod crustaceans for the southern tip of South America (Gorny, 1999; Arntz et al., 1999) were found in our 131 sampling tows (Table 1). From the total of 73,109 decapod individuals caught during 1999 and 2000, the most abundant species were Munida subrugosa and $M$. gregaria, which constituted 87 and $7 \%$ of the total decapod fraction respectively. Hereafter, M. subrugosa and M. gregaria are excluded from further analyses.

TABLE 1. - Benthic decapod crustacean species captured in the Argentine sector of the Beagle Channel. The relative proportion is the percentage of individuals of each species in relation to the total number of non-galatheid decapods caught $(n=4,192)$. The frequency of occurrence is the percentage of trawls $(n=131)$ in which each species occurred. Density is in individuals $\cdot 10,000 \mathrm{~m}^{-2} \pm 1$ standard deviation. Asterisks denote significant differences of U-Mann Whitney tests at $\mathrm{p}<0.05$ for the null hypothesis of equality of densities between depth strata. ${ }^{(1)}$ Results from Tapella (2002).

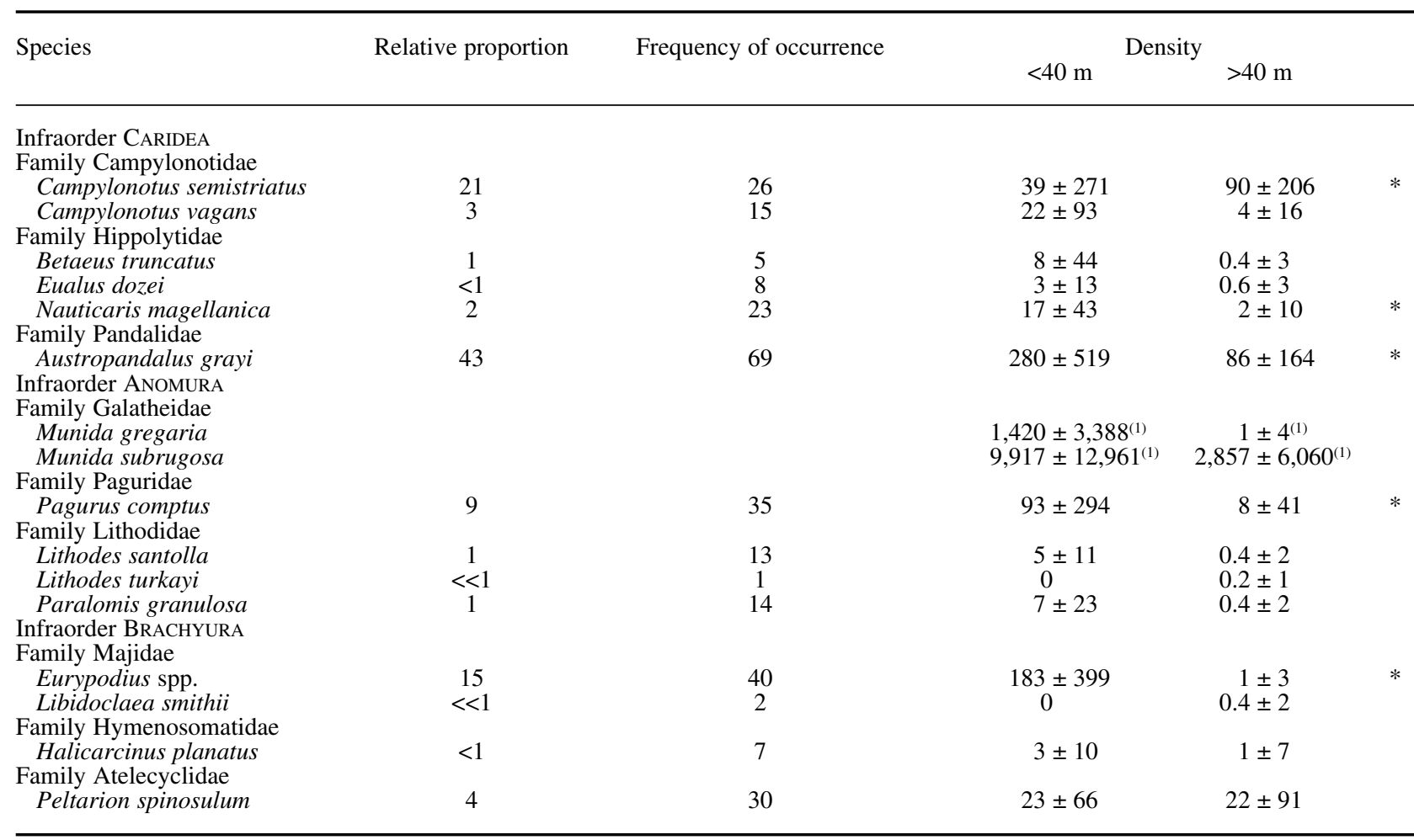




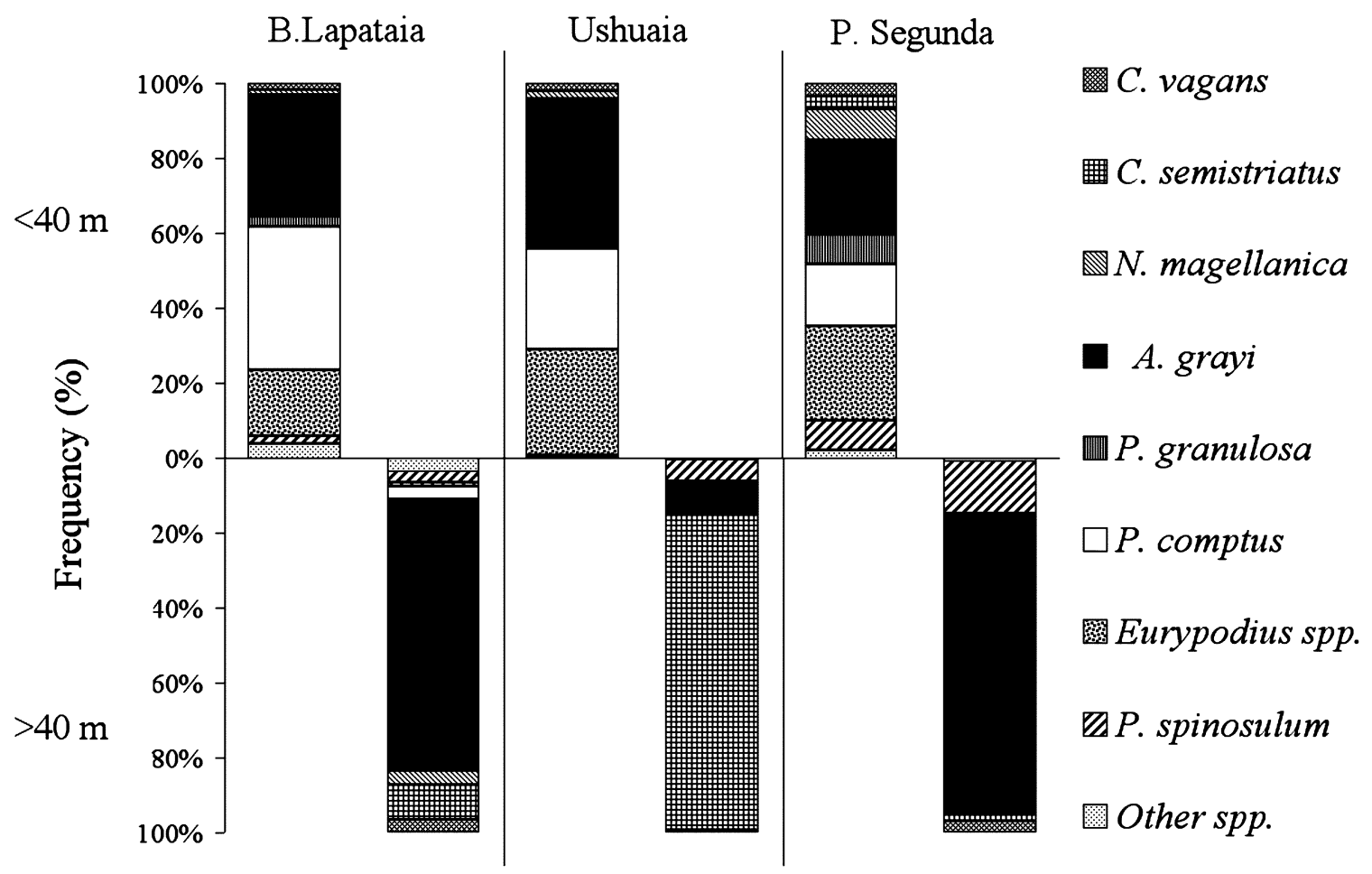

FIG. 2. - Specific composition of the non-galatheid decapod assemblage in the Beagle Channel for each area and depth strata. Different fillpatterns represent the proportion of individuals of each species over the total of individuals caught in each locality and depth stratum. "Other spp." includes species with a specific proportion $<1 \%$.

\section{Species composition}

Non-galatheid decapods comprised $6 \%$ of the total captures. In this group, carideans were the best represented taxa, constituting $70 \%$ of the individuals caught $(\mathrm{n}=2,923)$. The pandalid shrimp Austropandalus grayi was the dominant species in our captures (Table 1). Brachyurans constituted $20 \%$ of the decapod fraction, with Eurypodius spp. being the most frequent and abundant species. Among nongalatheid anomurans, the hermit crab Pagurus comptus was the most abundant and accounted for 9\% of the individuals captured. Austropandalus grayi was the most frequent species, followed by the crabs Eurypodius spp., Pagurus comptus and Peltarion spinosulum (Table 1). The commercially exploited crabs Lithodes santolla and Paralomis granulosa appeared in $<15 \%$ of our samples.

The decapod crustacean assemblage of the Beagle Channel changed with depth (Fig. 2). At $<40 \mathrm{~m}$ depth, the specific composition was similar at the three sampling locations, with Austropandalus grayi, Pagurus comptus and Eurypodius spp. as the best represented species. At $>40 \mathrm{~m}$ depth, Austropandalus grayi was the dominant species at Bahía Lapataia and Punta Segunda. However, at
Ushuaia, the shrimp Campylonotus semistriatus accounted for $\sim 80 \%$ of the total average density of decapods, followed by $A$. grayi and $C$. vagans (c.f. Fig. 3). Only two species, Lithodes turkayi and Libidoclaea smithii, were exclusive to the $>40 \mathrm{~m}$ depth stratum (Table 1).

\section{Density of decapod crustaceans}

The overall density of non-galatheid decapods was influenced by depth and location (Tables 2 and 3). At Bahía Lapataia, decapod density was similar in both depth strata (Table 2; planned comparison $\mathrm{F}=0.008 ; \mathrm{p}=0.93$ ), and significantly lower than the densities at the other two locations (planned comparison $\mathrm{F}=24.23 ; \mathrm{p}<0.01$ ). At Ushuaia and Punta

TABLE 2. - Average density (individuals $\cdot 10,000 \mathrm{~m}^{-2}$ ) of nongalatheid decapods in the Beagle Channel, for each sampling locality and depth stratum. Values in parenthesis are standard deviations.

\begin{tabular}{cccc}
\hline & Bahía Lapataia & Ushuaia & Punta Segunda \\
\hline$<40 \mathrm{~m}$ & 8.8 & 64.4 & 60.6 \\
& $(44.2)$ & $(268.7)$ & $(235.3)$ \\
$>40 \mathrm{~m}$ & 7.3 & 18.1 & 12.9 \\
& $(43.1)$ & $(91.9)$ & $(69.1)$ \\
\hline
\end{tabular}


TABLE 3. - Analysis of variance to test the null hypothesis of equality of non-galatheid decapod densities among localities and depth strata. References: MS: mean squares, DF: degrees of freedom, F: F-statistic, p: probability of rejecting the null hypothesis when the null hypothesis is true.

\begin{tabular}{lcccc}
\hline Source & MS & DF & F & $p$ \\
\hline Depth & 4.49 & 1 & 17.16 & $<<0.001$ \\
Locality & 3.42 & 2 & 13.07 & $<<0.001$ \\
Depth x Locality & 1.12 & 2 & 4.29 & 0.016 \\
\hline
\end{tabular}
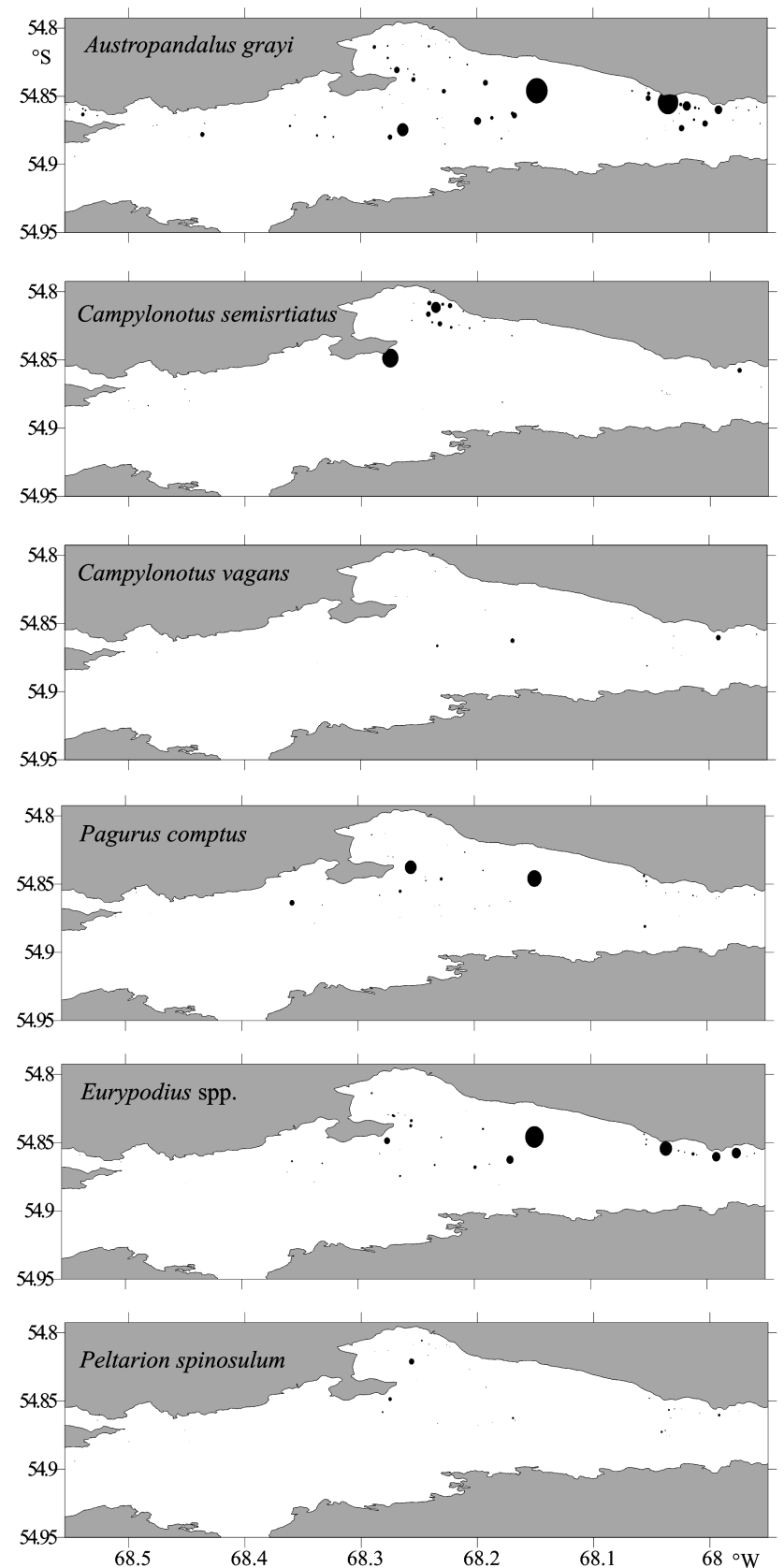

Segunda, the decapod density decreased significantly with depth (planned comparison $\mathrm{F}=28.81$; $\mathrm{p}<0.01)$.

For the majority of the most frequent species, densities were significantly higher in the $<40 \mathrm{~m}$ depth stratum (Table 1). Exceptions were Campylonotus semistriatus, whose density increased significantly with depth, and Peltarion spinosulum, whose density was similar in both depth strata.

Tows performed near the coast and islands and in the vicinities of the kelp forests yielded the largest decapod densities (Fig. 3). For most species, hauls that yielded $>700$ individuals $\cdot 10,000 \mathrm{~m}^{-2}$ were achieved at $<30 \mathrm{~m}$ depths, and were located in the shallows around the Bridges Islands and the Ushuaia location (c.f. Fig. 1, 3) and off Punta Segunda.
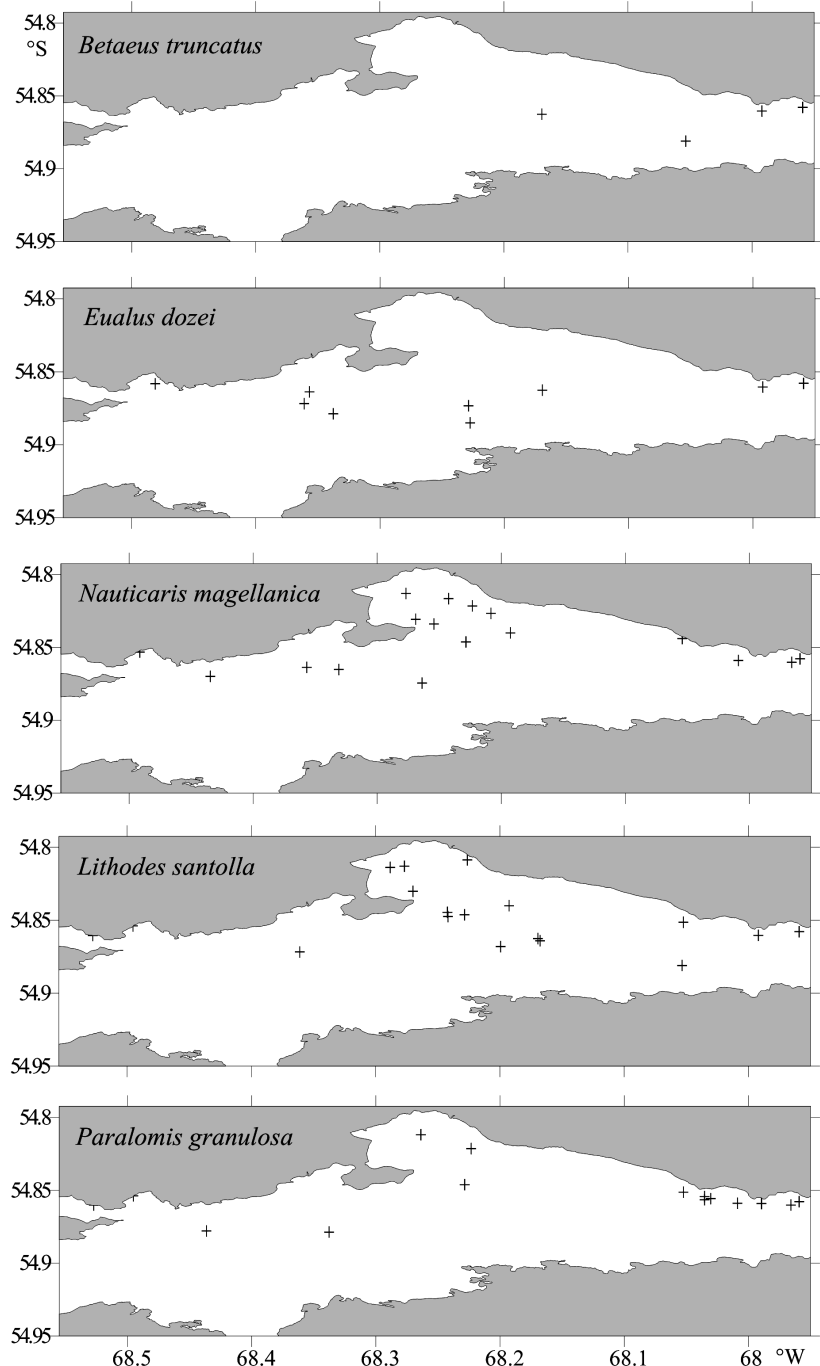

FIG. 3. - Specific spatial distribution of non-galatheid decapod crustaceans in the Beagle Channel. (Left) Density plots of species with $>500$ individuals $\cdot 10,000 \mathrm{~m}^{-2}$ at least at one station. In these maps plot size is proportional to the maximum density of Austropandalus grayi, the most abundant species. (Right) Species with densities lower than 500 individuals $\cdot 10,000 \mathrm{~m}^{-2}$ at all stations were plotted with + when present. 
TABLE 4. - Analysis of variance to test the null hypothesis of equality of diversities (Shannon Index) among localities and depth strata. References: MS: mean squares, DF: degrees of freedom, F: Fstatistic, p: probability of rejecting the null hypothesis when the null hypothesis is true.

\begin{tabular}{lcccr}
\hline Source & MS & DF & F & p \\
\hline Depth & 9.90 & 1 & 26.53 & $<<0.001$ \\
Locality & 0.48 & 2 & 1.28 & 0.281 \\
Depth x Locality & 2.03 & 2 & 5.44 & 0.006 \\
\hline
\end{tabular}

Similarly, species with $<500$ individuals $\cdot 10,000 \mathrm{~m}^{-2}$ occurred associated with these shallow waters.

\section{Diversity of the decapod assemblage}

Overall, the diversity of the non-galatheid decapod assemblage was influenced by depth (Table 4). In Ushuaia and Punta Segunda, the decapod diversity decreased significantly with depth (planned comparison $\mathrm{F}=47.12$, $\mathrm{p}<0.01$ ). At $<40 \mathrm{~m}$ a higher number of equally abundant species yielded a high diversity, whereas at $>40 \mathrm{~m}$ richness was lower than at $<40 \mathrm{~m}$, with one clearly dominant species for each location (C. semistriatus at Ushuaia and A. grayi at Punta Segunda). In contrast, at Bahía Lapataia decapod diversity was similar in both depth strata (Table 5; planned comparison $\mathrm{F}=0.004, \mathrm{p}=0.95$ ) and similar in average $(<40$ and $>40 \mathrm{~m})$ to the other two locations (planned comparison $\mathrm{F}=2.56, \mathrm{p}=0.11$ ). At Bahía Lapataia, diversity remained constant regardless of depth, mainly as a consequence of the increase in richness and the decrease in evenness with depth. At all three locations at $>40 \mathrm{~m}$ one species was clearly dominant (Fig. 2), making evenness lower in this depth stratum (Table 5).

Decapod diversity correlated positively with the density of algae and polychaete tubes $(\mathrm{r}=0.42$ and $\mathrm{r}=0.32 ; \mathrm{p}<0.01$ respectively). The highest algae density was found at Ushuaia and Punta Segunda at $<40$ $\mathrm{m}$ (Table 6). Polychaete tubes were most abundant at
TABLE 5. - Averages of Shannon diversity, richness, and evenness indexes of the assemblage of non-galatheid decapod crustaceans for each locality at each depth stratum. Values in parenthesis are standard deviations.

\begin{tabular}{|c|c|c|c|c|}
\hline & & Bahía Lapataia & Ushuaia & Punta Segunda \\
\hline Diversity $(\mathrm{H})$ & $\begin{array}{l}<40 \mathrm{~m} \\
>40 \mathrm{~m}\end{array}$ & $\begin{array}{l}0.75(0.41) \\
0.74(0.45)\end{array}$ & $\begin{array}{l}1.37(0.59) \\
0.51(0.53)\end{array}$ & $\begin{array}{l}1.41(0.75) \\
0.52(0.59)\end{array}$ \\
\hline $\begin{array}{l}\text { Richness } \\
{\left[\mathrm{R}=\log _{2} \text { (spp.)] }\right.}\end{array}$ & $\begin{array}{l}<40 \mathrm{~m} \\
>40 \mathrm{~m}\end{array}$ & $\begin{array}{l}1.03(0.86) \\
1.43(0.96)\end{array}$ & $\begin{array}{l}2.00(0.84) \\
1.00(0.90)\end{array}$ & $\begin{array}{l}1.95(0.83) \\
0.88(0.80)\end{array}$ \\
\hline $\begin{array}{l}\text { Evenness } \\
(\mathrm{E}=\mathrm{H} / \mathrm{R})\end{array}$ & $\begin{array}{l}<40 \mathrm{~m} \\
>40 \mathrm{~m}\end{array}$ & $\begin{array}{l}0.76(0.22) \\
0.58(0.29)\end{array}$ & $\begin{array}{l}0.71(0.18) \\
0.52(0.23)\end{array}$ & $\begin{array}{l}0.71(0.20) \\
0.59(0.27)\end{array}$ \\
\hline
\end{tabular}

Punta Segunda at $<40 \mathrm{~m}$. On the other hand, fine litterfall of terrestrial origin was most abundant at Bahía Lapataia at $<40 \mathrm{~m}$.

\section{DISCUSSION}

Previous studies on the distribution of decapod crustaceans in the waters of the Beagle Channel have yielded only semi-quantitative data (Arntz et al., 1999). By contrast, the small-scale sampling adopted in this study provided fully quantitative data, allowing more accurate estimations of species density and diversity of the decapod assemblage.

In this study, abundances of some species could have been underestimated. Captures of the commercially important lithodids Lithodes santolla and Paralomis granulosa were low, contrasting with fishery landings. For example, in the summer of 1996 the mean biomass of $P$. granulosa was estimated in 9.7 $\mathrm{t} \cdot \mathrm{km}^{-2}$ (Iorio et al., 1996). Differences in captures between this study and Arntz et al. (1999) and the actual abundance of lithodid crabs can be explained by the way in which different trawl nets work. Submarine video cameras showed that lithodids can perceive and escape the trawl by running outside the net path (PPB, personal observations). Moreover, our trawl net, without the usual line of chains ahead of

TABLE 6. - Average density of algae, fine litterfall and polychaete tubes for each locality and depth stratum.

\begin{tabular}{lccc}
\hline & & Bahía Lapataia & Ushuaia \\
\hline Algae & $<40 \mathrm{~m}$ & $1.13(2.59)$ & $31.88(75.95)$ \\
$\left(\mathrm{kg} \cdot 10,000 \mathrm{~m}^{-2}\right)$ & $>40 \mathrm{~m}$ & $1.25(2.06)$ & $0.12(0.34)$ \\
$\mathrm{Litterfall}$ & $<40 \mathrm{~m}$ & $82.67(273.6)$ & $35.17(136.2)$ \\
$\left(\mathrm{g} \cdot 10,000 \mathrm{~m}^{-2}\right)$ & $>40 \mathrm{~m}$ & $34.08(83.47)$ & $0.22(0.63)$ \\
$\begin{array}{l}\text { Chaetopterus spp. tubes } \\
\left(\mathrm{kg} \cdot 10,000 \mathrm{~m}^{-2}\right)\end{array}$ & $<40 \mathrm{~m}$ & $4.51(10.13)$ & $1.40(3.18)$ \\
\hline
\end{tabular}


its mouth that remove the superficial infauna, cannot capture buried specimens like the crab Peltarion spinosulum, which lives partially buried in burrows on soft bottoms of sand or mud (Gorny, 1999). Furthermore, Acanthocyclus albatrossis was absent from our samples, mainly because in the Beagle Channel this species is intertidal and/or associated with kelp holdfasts (Vinuesa et al., 1999; Brusca et al., 2000) that were not sampled in this study.

The composition, density, and diversity of the non-galatheid decapod fauna in the Beagle Channel are strongly influenced by depth. Our findings coincide with general trends in the distribution of the decapod fauna in the south of the Southern Hemisphere: Anomura and Brachyura are most abundant in shallow waters (i.e. $<100 \mathrm{~m}$ ) whereas Caridea are dominant in deep waters (c.f. Gorny, 1999). Our results suggest that between 4-262 m, albeit in a limited depth range compared with previous studies (c.f. Arntz et al., 1999), benthic decapods show a clear differential vertical distribution.

The composition of the benthic decapod assemblage in the Beagle Channel was similar to that of shallow waters of the eastern entrance of the Beagle Channel (Southern Islands after Arntz et al., 1999). Munida spp. represented the overwhelming proportion of $>90 \%$ of the decapods captured (see also Arntz et al., 1999). Four of our most frequent nongalatheid decapods (i.e. Austropandalus grayi, Eurypodius spp., Pagurus comptus, Peltarion spinosulum) were also reported as the dominant species for the Southern Islands (Arntz et al., 1999). Nevertheless, in our samples A. grayi was clearly dominant and Campylonotus semistriatus was among the three best represented species (Table 1, Fig. 3).

Density of non-galatheid decapod crustaceans decreased significantly with depth. The same pattern was found for Munida spp. and therefore reveals a general pattern for decapods inhabiting our study area (Tapella, 2002). Average abundance of Munida spp. was significantly higher at $<40 \mathrm{~m}$ than at $>40 \mathrm{~m}$ depth stratum: $11,870 \pm 13,990$ and 2,730 \pm 5,940 individuals $\cdot 10,000 \mathrm{~m}^{-2}$ respectively (KolmogorovSmirnov Test: $\mathrm{D}=0.56, \mathrm{p}<0.01$; Tapella, 2002). The overall average density of Munida subrugosa in our study area was 6,780 $\pm 11,010$ individuals $\cdot 10,000$ $\mathrm{m}^{-2}$, a value that is 35 times the overall average density of our most abundant non-galatheid decapod, Austropandalus grayi (191.1 \pm 408.4 individuals . $10,000 \mathrm{~m}^{-2}$ ). The highest densities of non-galatheid decapods were registered in tows performed near the coast and around the Bridges Islands (Fig. 3). These areas are characterised by large extensions of kelp forests at depths down to $40 \mathrm{~m}$ (Kühnemann, 1970).

The diversity of the non-galatheid decapod assemblage decreased significantly with depth, and was higher at Ushuaia and Punta Segunda at $<40 \mathrm{~m}$ (Table 4). These results are coincident with the fact that almost no algae or tubes of the polychaete Chaetopterus spp. were collected in deep tows, or at Bahía Lapataia. Algae, as well as polychaete tubes, create a three-dimensional habitat. Therefore, high decapod density and diversity at $<40 \mathrm{~m}$ depth could be related to the presence of kelp forests of Macrocystis pyrifera and other three-dimensional stuctures. Kelp holdfasts play an important role as a mechanical shelter, refuge from predators and nursery grounds for species that inhabit them (Ojeda and Santelices, 1984). In the Beagle Channel, in terms of biomass, decapods are one of the most important groups inhabiting the holdfasts, along with echinoderms, mollusks and polychaetes (Brusca et al., 2000). The most abundant decapod species living in the holdfasts are Pagurus comptus, Nauticaris magellanica and Paralomis granulosa. Furthermore, holdfasts of $M$. pyrifera are likely to act as nursery grounds for the economically important Paralomis granulosa and Lithodes santolla. Hence, kelp forests could be responsible for providing shelter for certain species whose individuals migrate, and therefore increase density and diversity at $<40 \mathrm{~m}$ depth.

The low overall decapod density and diversity found at Bahía Laptaia could be explained by the fact that this area constitutes an environment with clear estuarine characteristics given by an important inflow of fresh water produced by melting snow, along with the particulate organic matter from terrestrial origin that this water transports (see also Isla et al., 1999; Tapella, 2002). Munida gregaria was found to be most abundant at Bahía Lapataia and almost absent from Punta Segunda (Tapella, 2002). This species is known to be associated with places with high concentrations of suspended sediment, as well as a high input of fresh water (c.f. Rayner, 1935), therefore sustaining the idea that Bahía Lapataia offers conditions that favour deposit feeders.

The composition of the benthic decapod fauna in the Beagle Channel found in this study is comparable to that of South Georgia, which has been proposed as Antarctic by Gorny (1999). Nine of the sixteen benthic decapod species found in the Beagle Channel also occur in South Georgia (c.f. Gorny, 1999), whereas none of them occur on the Antarctic continental slope (Gorny, 1999 revised by Thatje, 
2003). At two locations, Shag Rocks (53⒉' $\left.44^{\circ} 46^{\prime} \mathrm{W}\right)$ and north of South Georgia $\left(53^{\circ} 24^{\prime} \mathrm{S}\right.$ $42^{\circ} 42^{\prime} \mathrm{W}$ ), samples are dominated by Magellan decapods (i.e. Campylonotus semistriatus, Eurypodius spp. or the lithodid Paralomis spinosissima), whereas south of South Georgia (54⒉ $27^{\prime} \mathrm{S} 35^{\circ} 42^{\prime} \mathrm{W}$ and $54^{\circ} 24^{\prime} \mathrm{S} 35^{\circ} 35^{\prime} \mathrm{W}$ ) samples yielded exclusively the Antarctic shrimp Notocrangon antarcticus (Romero et al., 2003). These observations suggest that the Magellan decapod fauna extends eastwards to South Georgia, which is probably a transitional area for the distribution of the Magellanic and Antarctic decapod faunas, as suggested by Romero et al. (2003).

Typical Antarctic shrimps such as Chorismus antarcticus, C. tuberculatus, Notocrangon antarcticus, and Nematocarcinus lanceopes were absent from our samples, despite being known to extend their distribution range as far as the southern tip of South America (Arntz et al., 1999; Gorny, 1999). Antarctic shrimps occurring in the Southern Islands were found on the continental slope at depths $>1100$ m (Arntz et al., 1999; Fahrbach and Gerdes, 1997). The Beagle Channel is a semi-closed basin with relatively shallow entrances $<100 \mathrm{~m}$ depth (Antezana, 1999a) and estuarine characteristics (Isla et al., 1999). Although Antezana (1999b) suggests the existence of potential intrusions of Antarctic meroplankton into the channel/fjord system, we did not find any adults corresponding to such species. This sustains the idea that the channel/fjord system is very different from the open ocean surroundings. Environmental constraints, such as low depths and salinities, could be acting as barriers for the Antarctic fauna to extend its distribution into the Beagle Channel (c.f. Antezana, 1999b).

The high abundance of Munida spp. (Gorny and Retamal, 2000; Tapella, 2002), their different commercial uses (Lovrich et al., 1998) and the decreasing yields of the lithodid fishery (Lovrich, 1997) will probably lead to the future commercial exploitation of galatheid crabs. The fishery will probably target grounds with the highest yields, i.e. $<40$ m depth, which are coincident with the highest diversity of the decapod fauna associated with Munida spp. Bottom trawls are known to have a highly negative impact on both the benthic invertebrate communities and the benthic habitat structure (e.g. Prena et al., 1999; Wion and McConnaughey, 2000). Therefore, a trawling fishery would involve a threat of impoverishment of the Beagle Channel epibenthic diversity.

\section{ACKNOWLEDGMENTS}

Thanks are due to A. Chizzini, A. Ferlito, F. Rouaux and N. Garibaldi for field and laboratory assistance. Carlos F. Balestrini, Servicio de Hidrografía Naval, kindly provided the digital map of the Beagle Channel. Two anonymous referees are thanked for making useful comments on an earlier version of the manuscript. This project was financed by grants of the Consejo Nacional de Investigaciones Científicas y Técnicas (CONICET; PIP 4307 to J.H. Vinuesa and PEI 470 to G.A. Lovrich), the Fundación Antorchas, and the ESK and HJPB philanthropic foundations. This work was part of the License degree thesis in biology of PPB at the University of Buenos Aires. FT and MCR have research fellowships from the CONICET.

\section{REFERENCES}

Antezana, T. - 1999a. Hydrographic features of Magellan and Fuegian inland passages and adjacent Subantartic waters. Sci. Mar., 63(Suppl. 1): 23-34.

Antezana, T. - 1999b. Plankton of Southern Chilean fjords: trends and linkages. Sci. Mar., 63 (Suppl. 1): 69-80.

Arntz, W.E., T. Brey and V. Gallardo. -1994. Antarctic zoobenthos. Oceanog. Mar. Biol.: Ann. Rev., 32: 241-304.

Arntz, W.E. and M. Gorny. - 1996. Cruise report of the joint Chilean-German-Italian Magellan 'Victor Hensen' Campaign in 1994. Ber. Polarforsch., 190: 1-113.

Arntz, W.E., M. Gorny, R. Soto, M.A. Lardies, M.A. Retamal and I. Wehrtmann. - 1999. Species composition and distribution of decapod crustaceans in the waters off Patagonia and Tierra del Fuego, South America. Sci. Mar., 63(Suppl. 1): 303-314.

Balestrini, C.F., G. Manzella and G.A. Lovrich. - 1998. Simulación de corrientes en el Canal Beagle y Bahía Ushuaia, mediante un modelo bidimensional. Serv. Hidrogr. Naval. Inf. Téc., 98: 1-58.

Boschi, E.E., C.E. Fischbach and M.I. Iorio. - 1992. Catálogo ilustrado de los crustáceos estomatópodos y decápodos marinos de Argentina. Frente Marítimo, 10 A: 7-94.

Brusca, M., G.A. Lovrich, M.C. Romero, J.A. Calcagno and F. Tapella. - 2000. Efectos del corte del dosel de Macrocystis pyrifera (Phaeophyta) sobre la fauna asociada a su grampón de fijación. IV Jornadas Nacionales de Ciencias del Mar, Puerto Madryn, Argentina.

Crame, J.A. - 1999. An evolutionary perspective on marine faunal connections between southernmost South America and Antarctica. Sci. Mar., 63(Suppl. 1): 1-14.

Fahrbach, E. and D. Gerdes. - 1997. The expedition Antarktis XIII/4-5 of the Research Vessel "Polarstern" in 1996. Ber. Polarforsch., 239: 1-126.

Garth, J.S. - 1957. Reports of the Lund University Chile Expedition 1948-1949. 29. The Crustacea Decapoda Brachyura of Chile. Lund Univ. Arsskr., N.F. 2, 53(7): 3-127.

Gorny, M. - 1999. On the biogeography and ecology of Southern Ocean decapod fauna. Sci. Mar., 63(Suppl. 1): 367-382.

Gorny, M. and M. A. Retamal. - 2000. Primeras observaciones mediante video submarina y estimación de abundancia de crustáceos decápodos y del megabentos en la Región Magallánica. Ciencia Tec. Mar, in press.

Gutt, J., E. Helsen, W.E. Arntz and A. Buschmann. - 1999. Biodiversity and community structure of the mega-epibenthos in the Magellan region (South America). Sci. Mar., 63(Suppl. 1): 155-170.

Holthuis, L.B. - 1952. Reports of The Lund University Chile Expedition 1948-49. 5. The Crustacea Decapoda Macrura of Chile. Lunds Univ. Arsskr. N.F. 2, 47(10): 1-109. 
Iorio, M.I., J. Wyngaard and M. Isla. - 1996. Campaña centollón Canal Beagle - Diciembre 1996. Inf. INIDEP, 22 pp.

Isla, F., G. Bujalesky and A. Coronato. - 1999. Procesos estuarinos en el Canal Beagle, Tierra del Fuego. Rev. Asoc. Geol. Arg., 54: 307-318.

Kühnemann, O. - 1970. Algunas consideraciones sobre los bosques de Macrocystis pyrifera. Physis, 29: 273-296.

Lovrich, G.A. - 1997. La pesquería mixta de centollas Lithodes santolla y Paralomis granulosa (Anomura: Lithodidae) en Tierra del Fuego, Argentina. Inv. Mar., Valparaíso, 25: 41-57.

Lovrich, G.A., M.A. Casalinuovo, S.I. Molina, C. Cárcamo and R. Pierotti. - 1998. Las langostillas Munida subrugosa y M. gregaria (Decapoda, Anomura) como potencial recurso económico patagónico. Nat. Patagónica, 6: 89-92.

Magurran, A.E. - 1988. Ecological Diversity and Its Measurement. Chapman and Hall, London.

Mutschke, E. and M. Gorny. - 1999. The benthic decapod fauna in the channels and fjords along the South Patagonian Icefield, Southern Chile. Sci. Mar., 63(Suppl. 1): 315-319.

Ojeda, F.P. and B. Santelices. - 1984. Invertebrate communities in holdfasts of the kelp Macrocystis pyrifera from southern Chile. Mar. Ecol. Prog. Ser., 16: 65-73.

Prena, J., P. Schwinghamer, T.W. Rowell, D.C. Gordon Jr., K.D. Gilkinson, W.P. Vass and D.L. McKeown. - 1999. Experimental otter trawling on a sandy bottom ecosystem of the Grand Banks of Newfoundland: analysis of trawl bycatch and effects on epifauna. Mar. Ecol. Prog. Ser., 181: 107-124.

Rayner, G.W. - 1935. The Falkland species of the crustacean genus Munida. Discovery Rep., 10: 212-245.

Retamal, M.A. - 1973. Contribución al conocimiento de los Decápodos de la Región Magallánica. Gayana, 29: 1-20.
Retamal, M.A. - 1981. Catalogo ilustrado de los crustáceos decápodos de Chile. Gayana, 44: 1-110.

Retamal, M.A. - 2000. Decápodos de Chile. World Biodiveristy Database. CD-ROM Series. ETI-UNESCO.

Retamal, M.A. and M. Gorny. - 2001. Decápodos de los fiordos de Chile (Cimar-Fiordo 3). Ciencia Tec. Mar, 24: 91-97.

Romero, M.C., F. Tapella, G.A. Lovrich and S. Thatje. - 2003. Reproductive modes and distribution of benthic decapod crustaceans along the Scotia Arc. Ber. Polarforsch., 462: 67-72.

Sokal, R.R. and F.J. Rohlf. - 1995. Biometry - The Principles and Practice of Statistics in Biological Research. W.H. Freeman and Company, New York.

Tapella, F. - 2002. Reproducción, crecimiento, distribución y abundancia de la langostilla Munida subrugosa (Anomura, Galatheidae) del Canal Beagle, Tierra del Fuego, Argentina. Doctoral thesis, Univ. Nac. Córdoba, Argentina.

Thatje, S. - 2003. Campylonotus arntzianus, a new species of the Campylonotidae (Crustacea: Decapoda: Caridea) from the Scotia Sea (Antarctica). Polar Biol., 26: 242-248.

Torti, M.R. and E.E. Boschi. - 1973. Nuevos aportes al conocimiento de los crustáceos decápodos Caridea del género Campylonotus Bate 1888. Physis, 84A: 65-84.

Vinuesa, J.H., G.A. Lovrich and F. Tapella. - 1999. New localities for Crustacea Decapoda in the Magellan region, southern South America. Sci. Mar., 63(Suppl. 1): 321-323.

Wion, D.A. and R.A. McConnaughey. - 2000. Mobile Fishing Gear Effects on Benthic Habitats: A Bibliography. NOAA Tech. Mem. NMFS-AFSC, 116: 1-167.

Scient. ed.: W.E. Arntz 